Anales de Literatura Hispanoamericana

ISSN: 0210-4547

http://dx.doi.org/10.5209/alhi.66799

\title{
De la Teoría del túnel a Último round: apuntes para una poética de Cortázar
}

Izara Batres Cuevas ${ }^{1}$

Resumen. La imbricación de poesía y prosa en la obra de Julio Cortázar y el proceso literario de interpenetración creativa con París que hace que el espíritu poético de la ciudad quede reflejado en las obras de Cortázar, al mismo tiempo que él escribe París desde una mirada poética, son los puntos de los que partimos para conformar este artículo. Se trata, también, de un proceso personal, puesto que las fases en que se divide se corresponden con los estadios vitales de Cortázar. Todo ello quedará recogido en la síntesis heterogénea de su libro almanaque Último round, pero, para comprender este proceso, antes debemos analizar las bases de la literatura y poética de Cortázar recogidas principalmente en sus obras Teoría del túnel (compilación de ensayos escritos en 1947) y Para una poética (1954), y también en otros textos del escritor que se vinculan con el mencionado libro almanaque. Veremos, de este modo, la imbricación de poesía y narrativa, la génesis del concepto de intersticio, esencial en Cortázar, la propuesta de la figura del poetista frente al narrador decimonónico, y la semilla de una revolución literaria que Cortázar ya anticipaba a partir de la obra de autores como Joyce y cuya cristalización se hará visible en Último round.

Palabras clave: Cortázar; París; ósmosis; poética; teoría; Último round.

\section{[en] From the Teoría del túnel to the Último round: Notes for a Poetics of Cortázar Último round}

\begin{abstract}
In the Julio Cortazar's work, poetry and prose are imbricated and, from his arrival in Paris, Julio Cortázar begins a process of creative inter-penetration with the city that makes the poetic spirit of Paris is reflected in the works of Cortázar, at the same time that he writes from Paris from a poetic viewpoint, it is also a personal process, since the phases that divide them correspond with the life studies of Cortázar. All of this has been gathered in the varied synthesis of Último round, but, in order to understand this, first we should analyze the poetic theory of Cortázar and the bases of his narrative in Teoria del túnel (compilation of essays written in 1947) and in "Para una poética" from 1954, an other Cortázar's texts linked with Último round, in which Cortázar talks about intrinsic writing and about the common axial point between poetry and narrative that defines his writing. So we will see the interweaving that exists between narrative and poetry, the genesis of the concept of the gap and the proposal of the poet in the face of the nineteenth-century narrator, the seed of a literary revolution that Cortázar already anticipated and whose preface he observed in the works of authors such as Joyce and that will crystallize in Último round.
\end{abstract}

Keywords: Cortázar; Paris; osmosis; poetics; theory; Último round.

1 Universidad Camilo José Cela, Madrid. España.

E-mail: izarasua@hotmail.com 
Cómo citar: Batres Cuevas, I. (2019) De la Teoría del túnel a Último round: apuntes para una poética de Cortázar, en Anales de Literatura Hispanoamericana 48, 501-518.

En la obra de Julio Cortázar, poesía y prosa han estado imbricadas desde el comienzo de su etapa esteticista (como él decidió llamarla) hasta el final de su recorrido literario, pero siempre en una desigual simbiosis en la que la estructura en prosa queda subordinada al elemento poético, es decir, la escritura de Cortázar es poetista en el más profundo sentido que el escritor le otorga a este concepto, como inevitable hegemonía de la esencia poética sobre el enunciado formal.

Si bien, para el objeto de este artículo nos interesa la culminación del proceso de unión de esa poética con una utopía revolucionaria plasmada en un momento y lugar históricos, debemos partir primero de la génesis de tal proceso que despierta y culmina con la ciudad de París, y cuyo desarrollo tiene lugar a través de una permanente dialéctica de opuestos en las obras del escritor.

La literatura de Cortázar tiene una importante definición teórica en su ensayo "Para una poética" (1954), pero comienza a articularse ya desde las bases establecidas en la Teoría del túnel de 1947.

En este ensayo, fundamental para entender la obra de Cortázar, el escritor se centra primero en la creación narrativa y nos habla de "un cobayo, la novela", distinguiendo dos fases diferenciadas en la historia de la creación literaria. En una primera etapa, se plantean dos usos idiomáticos o posibilidades del lenguaje novelístico: el lenguaje estético, al que también llama "enunciativo o lógico" (Cortázar, 1994a: 82), y el lenguaje poético con el que se imbrica: "imagen metáfora, infinitos juegos de la analogía (1994a: 83).

La novela "comportará entonces asociación simbiótica del verbo enunciativo y del verbo poético, o, mejor, la simbiosis de los modos enunciativos y poéticos del idioma" (1994a: 82) Ambos lenguajes conforman lo que Cortázar llama "orden estético de la literatura" (1994a: 82), que es la articulación de esa doble posibilidad del lenguaje donde lo poético está supeditado a lo estético.

A estos dos niveles añade Cortázar "el aura poética de la novela" (1994a: 83), que podemos definir como una instancia extraverbal entendida como "atmósfera que se desprende de la situación en sí -aunque se la formule prosaicamente-, de los movimientos anímicos y acciones físicas de los personajes, del ritmo narrativo, las estructuras argumentales" (1994: 83).

Se trata de un

encantamiento poético que opera desde las formas verbales y al mismo tiempo nace de la aptitud literaria para escoger y formular situaciones sumidas, narrativa y verbalmente, en ciertas atmósferas, del mismo modo como se nos dan cargados de poesía y en plena vida cotidiana un episodio callejero, un gesto entrevisto en la distancia, un juego de luces (1994a: 83).

Este ejemplo del encantamiento poético extrapolado al terreno de la vida real es importante, puesto que constituirá el inicio de una segunda fase en la que el orden estético, como superestructura codificante de la arquitectura novelesca, "ha dejado de merecer la confianza del escritor rebelde"(1994a: 86). Lo que interesa a partir de ahora, dice Cortázar en su texto "Etéocles y Polinices", incluido en la Teoría del 
túnel, radica en "cómo se nos propone en la etapa moderna de la novela, el modus vivendi de lo enunciativo y lo poético" (1994a: 86).

A partir de este postulado, en el ensayo que da nombre al conjunto, "Teoría del túnel", Cortázar habla de un nuevo escritor que rompe los cánones del novelista decimonónico, al sentirse constreñido por ellos:

Nuestro escritor advierte en sí mismo, en la problematicidad que le impone su tiempo, que su condición humana no es reductible estéticamente y que por ende la literatura falsea al hombre a quien ha pretendido manifestar en su totalidad y en su multiplicidad; tiene conciencia de un radiante fracaso, de una parcelación del hombre a manos de quien mejor podía integrarlo y comunicarloº (1994a: 62).

Por lo tanto, se establece así la división del escritor en "dos grupos opuestos: el que informa la situación en el idioma (y esta sería la línea tradicional) y el que informa el idioma en la situación" (1994a: 64). Este último "se inclina con temerosa maravilla ante esos escritores del pasado en quienes asoma, proféticamente, la conciencia del hombre total, del hombre que sólo conviene en órdenes estéticos cuando los halla coincidentes con su libre impulso" (1994: 62).

Lejos de adaptarse a las formas lingüísticas para tratar de transmitir a través de ellas un pensamiento o sentimiento que quedaría reducido a un enunciado gramático, es preciso "hacer el lenguaje para cada situación" y "al recurrir a los elementos analógicos, prosódicos y aún estilísticos, necesarios para alcanzar la comprensión ajena, es preciso encararlos desde la situación para la cual se los emplea y no desde el lenguaje mismo" (1994a: 65).

Esta "agresión" contra el lenguaje literario convencional, contra las formas tradicionales, "tiene las características del túnel: destruye para construir" (1994a: 66).

La poesía se alza, entonces, contra la estructura del enunciado: "es el elemento poético el que de pronto se agita en ciertas novelas contemporáneas y muestra cierta voluntad imperialista" (1994a: 66). Dicho de otro modo, la poesía busca su fin último: trascender las estructuras fijas del enunciado.

Aquí, Cortázar ya no apunta a un lenguaje poético sino a un orden poético que se constituye como una sustitución del anterior, construcción tras la destrucción: "el orden estético cae porque ahora el escritor no encuentra otra posibilidad de creación que la del orden poético" (1994a: 87).

Tengamos en cuenta que Cortázar coincide con otros escritores en la consideración de la novela (y la ficción) como un "mecanismo cognitivo", es decir, la literatura es concebida por Cortázar como una empresa de conquista de la realidad [...] un instrumento verbal que permite al hombre conocer y conocerse. (Garrido Domínguez 2011: 177).

La novela es, entonces, la base de una nueva búsqueda en la que, como afirma Saldaña, "el poeta rechaza ahora el mundo natural, empírico, y aspira a conocer el sentido oculto y misterioso de las cosas, reinventando así la realidad" (2003: 79).

\footnotetext{
${ }^{2}$ En adelante, cuando mencionemos el ensayo "Teoría del túnel" lo pondremos entre comillas, mientras que utilizaremos la cursiva para referirnos al conjunto de ensayos en el que está englobado: Teoría del túnel.
} 
Esta rebelión de lo poético contra el uso fetiche, es ilustrada por Cortázar a través de dos personajes mitológicos (hijos de Edipo) que personifican, para el escritor, la idea del conflicto: "en el tiempo en que Etéocles y Polinices se toleraban por obra del novelista conciliador, la función del uso poético del lenguaje fincaba en el ornamento, la apoyatura, el pathos complementario de ciertas situaciones narrativas" (1994a: 87), es decir, que "el elemento poético cumplía un papel análogo al de la "música de fondo en las películas" (1994a:88).

Sin embargo, "el escritor rebelde da el paso definitivo, y el reclamo de un lenguaje solamente poético prueba que su mundo novelesco es ya sólo poesía [...] sólo denominable novela por razones escolares, y se cumplen accidentes, destinos y situaciones complejísimas pero todo ello dentro de una visión poética" (1994a: 90).

De este modo, "la síntesis estética de una situación con dos usos del lenguaje, resulta superada por el hecho poético libre de mecanismos dialécticos" (1994a:90). Hasta tal punto que seguir hablando de novela "carece de sentido" (1994a:90). El mecanismo tradicional de la novela ha cedido en favor de aquello que ya es "una manifestación poética total" (1994a: 91) y que abarca simultáneamente formas que sólo en apariencia lo son, como el teatro, el poema, la narración.

Es decir, "el paso del orden estético al poético entraña y significa la liquidación del distingo genérico Novela-Poema" (1994b: 149), ya que la manifestación poética total "abraza simultáneamente formas aparentes como el poema, el teatro, la narración” (1994b: 149).

En este punto de la teoría poética de Cortázar es donde más claramente vemos la urgencia de una subversión de los cánones y de una superación de los esquemas tradicionales en favor de una estructura abierta. A este respecto, señala MacMillan: "queda claro que ese formularse poéticamente no está necesariamente ligado al lenguaje poético, ya que puede asumir todos los modos" (2005: 34).

Desde la perspectiva de Cortázar, "hay un estado de intuición para el cual la realidad, sea cual fuere, sólo puede formularse poéticamente, dentro de modos poemáticos, narrativos, dramáticos: y eso porque la realidad, sea cual fuere, sólo se revela poéticamente" (Cortázar 1994b: 150).

Cortázar habla de la poesía como de una cualidad trans-genérica, no solo presente en los textos sino en la realidad de la experiencia vital. De hecho, la importancia de la analogía como elemento definidor de lo poético permite entonces que el concepto trascienda los límites de lo estrictamente literario.

Cortázar extrae la hondura del vínculo de poesía y surrealismo y menciona, en su texto "Muerte de Antonin Artaud", a Artaud como máximo ejemplo, a su juicio, de la "voluntad de sobrerrealizarse" (Cortázar 2006: 203), puesto que: "el surrealismo propone el reconocimiento de la realidad como poética y su vivencia legítima" (2006:203) y nos recuerda que Artaud, desde su batalla contra el fetiche, quería que los poemas se volvieran "verdaderos", y "que la vida saliera de los libros, de las revistas, de los teatros o de las misas" (2006: 203).

La poesía concebida como experiencia vital, lejos de ser música de fondo, guía, trasciende y compone la entera constelación del relato. El narrador ha dejado de narrar "la cosa" para transmitir lo que hay en su interior.

En su texto "El Conde y el vagabundo" (incluido en la Teoría del túnel), Cortázar nos traslada dos ejemplos nítidos de esta tendencia: Los cantos de 
Maldoror (1869) y Una temporada en el infierno (1873), de Lautréamont y Rimbaud respectivamente. La realidad poética que inventa Lautréamont en Los cantos de Maldoror, está "regida por la analogía antes que por la identidad" (1994a: 95). Así, "negándose a someter su realidad poética a los órdenes estéticos del lenguaje, superado por una avalancha de imágenes fulgurantes y deslumbramientos atroces, el Conde se deja hablar" (95) y nos transmite su "revelación" en la que ya no hay parcelación entre poema y novela, pues el texto es las dos cosas sin ser ninguna de ellas, libre de toda clasificación.

Lautréamont rompe el fetiche: "perfora la realidad racional y racionalista y formula con el único lenguaje posible una superrealidad que dilata vertiginosamente el ámbito aprehensivo del hombre, por vía y como consecuencia de esa fulgurante revelación" (97).

Desde la perspectiva de Cortázar, se trata simplemente de la "presentación poética del entero ámbito vital de un hombre" (96). Para Lautréamont, la literatura y la poesía han dejado de ser modos de manifestación existencial porque "lo poético es lo existencial, su expresión humana y su revelación como realidad última" (96).

Después llegarán, en esta misma línea, las aportaciones existenciales de Rimbaud -a quien Cortázar se refiere como "el vagabundo"-, que en su saison en enfer "logra una participación existencial de tal intensidad que liquida desde el comienzo todo lenguaje enunciativo" (98).

Rimbaud, consciente de la imposibilidad del lenguaje regular para revelar estados en los que el poeta "se adhiere a una inocencia esencial" (p.98), trata de transmitir (de hacer "notar", en palabras de Cortázar) la "experiencia poética" (98) comunicable sólo por "el mismo sistema de imágenes en el que la experiencia se propone"(98).

Podemos decir, por tanto, que estos autores supondrían un modelo de lo que, siguiendo el planteamiento de Mac-Millan, se denominaría "poesía existencial" (2005: 35), es decir, lo poético no radica ya, en primera instancia, en el lenguaje sino en algo anterior a este: la "experiencia poética", y en aquello que Mac-Millan denomina "la misteriosa comunicación de esa experiencia" (2005: 35).

La experiencia poética de un orden no reductible a la enunciación, y previa a la narración, se presta a un doble análisis desde dos enfoques distintos: uno más abstracto que nos remite al análisis de los orígenes del sentimiento poético y a la concepción del poeta como "mago metafísico", y otro más concreto, que remite al modo de comunicar esta experiencia irreductible al enunciado.

Empezando por el primero de ellos, en la cualidad "previa" de esa experiencia poética, observamos, por un lado la cualidad atemporal de la poesía, ya que no precisa del tiempo para adquirir su plenitud de sentido y habitualmente genera una línea de fuga que hace que el poeta salga del tiempo, lo cual alude a la "vinculación pre-científica" (Cortázar, 1994b: 268) del hombre, de la que Cortázar nos habla en su ensayo "Para una poética". Se trata de la "urgencia de aprehensión por analogía" (1994b: 268) que el individuo muestra "desde sus primeras operaciones sensibles e intelectuales" (p.268), es decir, una experiencia sensible previa a la científica.

\footnotetext{
${ }^{3}$ Cortázar utiliza este concepto en su "Para una poética" (1954) (véase en Julio Cortázar 1994: 280).
} 
Partiendo de esta vinculación del poeta con el estadio primero de "inocencia esencial", y considerando la metáfora como Cortázar la define: "forma mágica del principio de identidad" (1994b: 269), podemos comprender la hermanación que establece el escritor entre la figura del poeta y la del mago, miembro de una tribu primitiva cuyo sistema de pensamiento es previo a la lógica occidental.

Poeta y mago quedarían vinculados en lo referente a "la dirección analógica" (1994b: 269) de su pensamiento, concebida como "una facultad esencial, un sentido espiritual" (1994b: 269), y en cuanto que se hallan fuera de todo sistema conceptual "petrificante". Sus percepciones sensibles pueden considerarse por lo tanto cercanas a las formas primordiales, previas a la estructura lógica occidental.

Este concepto está presente también en El perseguidor, en el que es visible la teoría sobre la dirección analógica pre-científica, los estudios antropológicos en los que se inspiró Cortázar para escribirla y la relación establecida por Sosnowski entre estos preceptos y los pasajes cortazarianos entre modos existenciales.

Para Cortázar, la evolución del hombre en el terreno racional ha eliminado la "cosmovisión mágica" (1994b: 270), sustituyéndola por el método científico o por la articulación filosófica. Pero, "mientras de siglo en siglo se libraba el combate entre el mago y el filósofo, el curandero y el médico, un tercer agonista llamado poeta continuaba sin oposición alguna, una tarea extrañamente análoga a la actividad mágica primitiva" (1994b: 270).

Desde la perspectiva de Cortázar, la diferencia fundamental que presenta el poeta frente al mago - la que le salva de esta quema histórica- reside en que, a pesar de conceder, como él, un predominio al pensamiento intuitivo, el poeta es consciente de que "su certidumbre poética vale en cuanto poesía, y no en la técnica de la vida" (1994b: 273).

El poeta responde al esquema $\mathrm{A}=\mathrm{A}$, con la posibilidad de $\mathrm{A}=\mathrm{B}$, donde se hace visible "toda conexión analógica, toda imagen que enlaza datos determinados [...] la identificación que hace saltar al principio de identidad en pedazos" (1994b: 271) -más tarde veremos cómo esto tiene mucho que ver con las secretas correspondencias dadas desde la mirada poética-, pero el poeta es consciente de que este orden es válido sólo en el terreno poético, no en el de la vida, mientras que el primitivo "no tiene otra visión que la prelógica" (1994b: 273).

Así pues, el poeta, eterno navegante de dos aguas -y cuya riqueza esencial reside precisamente en esta confluencia-, "cede a la irrupción momentánea de tales certidumbres sin que ello interfiera fácticamente en sus nociones científicas" (1994b: 273).

Esta idea nos lleva a la segunda consideración del concepto de experiencia poética previa, la que se centra en cómo se da la revelación y en el medio en que esa experiencia incontable puede ser contada, lo cual nos orienta hacia un conflicto fundamental en la obra de Cortázar y que supone la base de 62/Modelo para armar: cómo contar el intersticio.

El poeta "entra en el mundo de las cosas mismas, no de los nombres que acaban borrando las cosas" (1994b: 270), y lo hace a través de esa irrupción momentánea que conforma un interregno o intersticio, concepto que adquiere capital importancia en la obra de Cortázar. 
Para Mac-Millan “en relación al cómo se da esa experiencia poética, lo esencial es la intersticialidad, se presenta de una manera que podríamos llamar intersticial" (2005: 42).

En este sentido, señala Baena, en su ensayo sobre la poesía de Juan Ramón Jiménez "La otra voz", que el poeta

fija en el instante de creación una dificultad, la paradoja del ser y no ser que se resuelve a través de la imagen poética como una verdad superior inherente al movimiento de la existencia, entre lo que fue y lo que será, la vida y la muerte, para alcanzar la plenitud del presente (2010: 85-86).

Es decir, que el momento de creación establece un "punto de fuga" (Baena 2010: 86), un espacio atemporal que abre la puerta a una otredad.

En su texto "El estado actual de la narrativa en Hispanoamérica", Cortázar habla de esta "erupción de lo desconocido", una "sensación terriblemente breve y fugaz de que existe un significado, una puerta abierta hacia una realidad que se nos ofrece pero que nosotros, tristemente, no somos capaces de aprender" (1994c: 99)

Tratando de explicar esta experiencia, afirma:

hay momentos de mi vida en los que por un instante dejo de ser quien habitualmente soy para convertirme en una especie de pasadizo. En mi interior o fuera de mí se abre de repente algo, un inconcebible sistema de receptáculos comunicantes hace que la realidad se vuelva porosa como una esponja; durante un momento, por desgracia breve y precario, lo que me rodea cesa de ser lo que era o yo dejo de ser quien soy o quien creo que soy, y en ese terreno en que las palabras sólo pueden llegar tarde e imperfectas para intentar expresar lo que no puede expresarse, todo es posible. (Cortázar 1994c: 97).

Cortázar cede a la irrupción momentánea de una experiencia poética que le traspasa. Dice ser "un poco pararrayos" (González Bermejo 1978: 43) de sus propios relatos, experiencias narradas casi en un proceso de escritura automática, pues

lo fantástico no aparece de forma áspera o directa, ni es cortante, sino que más bien se presenta de una manera que podríamos llamar intersticial, que se desliza entre dos momentos o dos actos en el mecanismo binario típico de la razón humana a fin de permitirnos vislumbrar la posibilidad latente de una tercera frontera, de un tercer ojo, como tan significativamente aparece en algunos textos orientales. (Cortázar 1994c: 99)

Por ello, en "Algunos aspectos del cuento" Cortázar confesaría:

en mi caso, la gran mayoría de mis cuentos fueron escritos -cómo decirlo- al margen de mi voluntad, por encima o por debajo de mi consciencia razonante, como si yo no fuera más que un médium por el cual pasaba y se manifestaba una fuerza ajena (1994b: 374). 
Esa suerte de "état-second"4 (Cortázar 2006: 86), línea de fuga que permite al poeta observar, escribir, ser permeado, da lugar a una definición de la irrupción extratemporal: "el intersticio se da como instantánea fractura del continuo" (Cortázar 2007, tomo I: 34). Así lo afirma Cortázar en su libro La vuelta al día en ochenta mundos.

Esta fractura en el continuo supondría un "avance en la realidad". Ello puede concluirse del texto "El conde y el vagabundo", donde Cortázar opina que la ruptura del "cordón umbilical estético y el ingreso en la poesía existencial" (1994a: 99) que realiza Rimbaud, así como la incursión en la superrealidad de Lautréamont, "literariamente más audaz que Rimbaud en este sentido" (1994a: 99) suponen "un avance en la realidad" (99).

Así, este pasaje hacia lo extratemporal que consigue la forma poética, constituye un avance que, por otro lado, conforma el primer germen de la unión de existencialismo y surrealismo en una misma escritura determinada por el orden poético, no por el estético.

La etapa de construcción que Cortázar inicia con el ensayo "Teoría del túnel" (que, como decíamos, da nombre al conjunto Teoría del túnel) empieza con la redefinición de estos humanismos cuya unión (concebida así por Cortázar desde el inicio) cristalizará en el poetismo, narración novelesca donde el poeta rige, sin anularlo, al narrador enunciativo (Cortázar, 1994a: 110) y en la figura del poetista: "escritor contemporáneo que se vuelca en la expresión poética pero persiste en sostener una literatura" (1994a:110).

El poetista, propuesto por Cortázar frente al narrador decimonónico, se reflejará también en el personaje de Morelli en Rayuela, y más tarde, veremos la gran relevancia que tal figura unificadora adquiere en Último round.

Cortázar entiende el avance en la realidad como un "salto", pues "el poeta y sus imágenes constituyen y manifiestan un solo deseo de salto, de irrupción, de ser otra cosa" (Cortázar 1994b: 279). Si la poesía busca trascender la palabra es porque no persigue la apariencia-cosa, sino la cosa "creada poéticamente, es decir, esenciada" (1994b: 280). La palabra "no vale ya como signo traductor de esa esencia sino como portadora de lo que al fin y al cabo es la cosa misma en su forma, su idea, su estado más puro y alto" (1994b:280).

Para Cortázar, "todo poeta parece haber sentido siempre que cantar un objeto (un tema) equivalía a apropiárselo en esencia” (281). Señala el escritor que

la música verbal es acto catártico por el cual la metáfora, la imagen (flecha lanzada al ente que mienta y que cumple simultáneamente el retorno de ese viaje intemporal e inespacial) se libera de toda experiencia significativa para no aludir y no asumir sino la esencia de sus objetos. Y esto supone, en un tránsito inefable, ser sus objetos en el plano ontológico. (Cortázar 1994b: 281).

Esta idea llevará a Cortázar a plantear la teoría del camaleón, que desarrollará en La vuelta al día en ochenta mundos, y en la que habla de la participación de las esencias por parte del poeta (ser que late con los diversos corazones del pulpo cósmico). Pero también tiene un claro vínculo con su concepto y expresión del

\footnotetext{
${ }^{4}$ Así lo denomina Cortázar en su ensayo "Del cuento breve y sus alrededores” (Cortázar 2006a, tomo I: 86).
} 
amor a lo largo de su trayectoria literaria: así, las primeras reflexiones sobre la Maga en Rayuela se vincularían con la forma de entender a Hélène en 62/Modelo para armar, mediante la dialéctica posesión-participación.

El ansia de posesión que Oliveira y Juan sienten hacia la Maga y Hélène, es, en realidad, un deseo de acceder a la esencia pero ésta es innombrable; el "ser" es todo y nada, sólo accesible en fugaces tomas de contacto.

En este sentido, el avance que supone el texto de La vuelta al día, "Morelliana siempre", radica en aclarar el medio de penetrar en tal esencia: es decir, este texto da el paso decisivo que va desde la participación en la esencia a través de la posesión, a dicha participación a través del amor, puesto que el acceso sólo tiene lugar desde la mirada del poeta, "con los ojos desollados por un fuego heracliteano" (Cortázar 2007, tomo II: 182): luz que ya se revela incipiente en Rayuela, sin haber alcanzado aún su definición.

A partir de ahí, la poética de Cortázar seguirá otro rumbo que culminará en el logro inconsciente de Último round: la fusión del poeta con la esencia perseguida.

Continuando nuestro recorrido, una vez definida la experiencia poética como avance en la realidad a través del intersticio, el problema viene con la manifestación textual de lo poético, cómo encontrar un género no-género, un lugar no-lugar para expresar lo inexpresable.

El hecho de que la obra sea concebida como una manifestación poética total, una vez superado el canon tradicional sometido al orden estético, amplia sus posibilidades de permeabilidad muy por encima de la estricta delimitación de los géneros literarios, $o$, en palabras de Mac-Millan, hace que la obra antes condicionada a un sólo género "se desborde en toda la gama de posibilidades genéricas que el lenguaje le ofrece" (2005: 37).

Así, en cada forma (sólo aparentemente género) el modo de transmitir la experiencia intersticial, nos recuerda Mac-Millan, se daría de un modo distinto (2005: 44). En el cuento, el pasaje se abriría a través de lo fantástico que se cuela en la realidad, nos recuerda Cortázar en su texto "La muñeca rota": "el misterio [...] está siempre entre, intersticialmente" (2006a, tomo I: 268).

En otro de los textos de Último round, "Del cuento breve y sus alrededores", añadiría: "sólo la alteración momentánea dentro de la regularidad delata lo fantástico" (Cortázar 2006a, tomo I: 80) En este sentido, hemos de tener en cuenta que, en su escritura, Cortázar desafía, al mismo tiempo, el paradigma mimético de la realidad y el antimimético. En el primero, "ficción y realidad aparecen como entidades continuas - la primera como una prolongación de la segunda- $y$, sin embargo, diferenciadas; cada una ocupa su lugar, aunque la ficción pretende crear la ilusión de que son la misma cosa" (Garrido Domínguez 2011:118).

El segundo paradigma (antimimético),

concibe los mundos ficcionales como algo que no surge directamente de la realidad sino como resultado de un proceso de producción imaginaria [...] Dicho paradigma parece haber surgido más bien como exigencia de la propia narrativa contemporánea y su irrefrenable tendencia a superar las fronteras de la mímesis. Por paradójico que parezca, existe en toda esta narrativa la tendencia a domesticar o, mejor, legitimar sus propias transgresiones y a presentar, en suma, 
la ficción como la otra cara de la realidad, cuando no a confundirse con ella (Garrido Domínguez 2011: 118).

El mundo ficcional construido por Cortázar, supone un desafío a los dos modelos o más bien una integración de ambos, ya que, como señala Garrido Domínguez, se trata de "un mundo híbrido" donde se mezclan "elementos pertenecientes al campo interno de referencia con otros tomados de la realidad empírica" (2011: 204).

De otro modo, el relato de la experiencia poética encontraría todo tipo de obstáculos, mientras que la escritura híbrida, esponja (en el sentido en que la entiende Cortázar), entra en todos los terrenos, participa de la respiración de todos los mundos, es el medio de comunicar la entrevisión.

Tal vez la definición más completa de este concepto de esponja nos la ofrece Cortázar en su texto introductorio a La vuelta al día en ochenta mundos ("Así se empieza") en el que habla de que librarse del "cangrejo de lo idéntico" para ganar "simultaneidad porosa", y nos aclara que

todo lo que sigue participa lo más posible de esa respiración de la esponja en la que continuamente entran y salen peces de recuerdo, alianzas fulminantes de tiempos y estados y materias que la seriedad, esa señora demasiado escuchada, consideraría inconciliables" (2007, tomo I: 7).

Así, Cortázar, firme partidario de esta simultaneidad porosa en todos los terrenos, asegura, en su ensayo "Del cuento breve y sus alrededores" que, a pesar de las diferencias entre ambas formas de lenguaje, "la génesis del cuento y del poema es la misma, nace de un extrañamiento, de un desplazarse que altera el régimen normal de la conciencia" (2006a, tomo I: 78). De hecho, un cuento breve en el que esté presente el elemento intersticial de lo fantástico, "no tiene una estructura de prosa" (2006a, tomo I: 68), sostiene Cortázar que, a continuación, nos proporciona una de las claves teóricas que nos permiten entender la poesía en prosa que teje en cada una de sus obras:

cada vez que me ha tocado revisar la traducción de uno de mis relatos [...] he sentido hasta qué punto la eficacia y el sentido del cuento dependían de esos valores que dan su carácter específico al poema y también al jazz: la tensión, el ritmo, la pulsación interna, lo imprevisto dentro de parámetros previstos (68)

El escritor afirma que estos relatos

respiran, no el narrador, a semejanza de los poemas perdurables, y a diferencia de toda prosa encaminada a transmitir la respiración del narrador, a comunicarla a manera de un teléfono de palabras [...] La comunicación se opera desde el poema o el cuento, no por medio de ellos. Y esa comunicación no es la que intenta el prosista, de teléfono a teléfono (2006a, tomo I: 78-79)

Lo que Cortázar nos transmite desde todas sus obras es, por tanto, esa experiencia poética existencial que alude a una superrealidad. Podemos decir, en resumen, que la apertura es existencialista y surrealista, tiene carácter de pasaje o intersticio, 
supone un avance y este avance liquida toda preeminencia del género sobre el contenido: "en un tiempo en que las etiquetas y los géneros ceden a una estrepitosa bancarrota, no es inútil insistir en esta afinidad [cuento-poesía] que muchos encontrarán fantasiosa" (2006a, tomo I: 78), señala Cortázar.

Mac-Millan ilustra esta idea de la expresión de la experiencia poética con la imagen del novelista que "debe escribir entreviendo, como quien coloca la punta de un zapato en territorio desconocido" (2005: 46). Para la autora, "toda la obra de Cortázar está escrita desde un intersticio" (2005: 44). Pero, así como suscribimos la primera afirmación de Mac-Millan, no podemos, sin embargo, proceder igual con esta última, pues, si atendemos a los textos escritos por Cortázar y a la visión que él mismo tenía de ellos, sería más adecuado decir que la obra de Cortázar nos llega traspasada de intersticio.

Como él mismo dice al respecto de 62, en su ensayo "La muñeca rota": se trata de generar "una porosidad virtual" (2006a, tomo I: 261) pues el único medio de "permitir el adelanto" es provocar "irrupciones intersticiales", pero, y esto es importante, "sin la pretensión de abarcar la entera superficie de la esponja fenoménica", tejida a través de ellos.

No obstante, sí nos sería dado afirmar que Último round es una obra-esponja, puesto que sigue esta misma premisa en cada uno de sus fragmentos, es decir, que, cumpliendo una ley de fractalidad muy cortazariana, cada uno de los textos permeables actúa como poro de la gran esponja que conforma el libro, en un recorrido hacia el acceso central.

Del mismo modo, los relatos de Cortázar pueden ser considerados relatos esponja compuestos a través de un swing que constantemente crea líneas de fuga (este concepto lo estudiaremos en el siguiente capítulo), como hace el jazz. Así, el no-espacio se rebela en una escritura automática y rítmica, en el juego entre materia antimateria (lo presente y lo ausente), que analizaremos en el capítulo dedicado a 62 y en el de Último round, y que está presente en todas sus obras a varios niveles: eón 5 cronos, capítulos prescindibles / capítulos no prescindibles, personajes y dobles, continuas alusiones de los personajes al estado extratemporal, el juego con las imágenes que en los libros almanaque crea continuos accesos, etc.

En este sentido, el hecho de que Cortázar pasara de 62 a Último round nos revela la llegada al punto culminante de un proceso. En realidad, 62 nos habla de la imposibilidad de narrar eso que sólo podrá contarse a través del juego Último round. Es decir, la forma novela de 62 es limitada; nace, inevitablemente con un para qué, mientras que la heterogeneidad permutante de Último round permite que la apertura y el avance en la realidad tengan lugar de una forma espontánea.

En palabras de Mac-Millan, en Último round "el principio intersticial se realiza en todos los planos textuales, tanto en los formales como en los de contenido, y se suscribe a un compromiso político, social y moral" (2005: 51).

El pasaje en este libro, se abre también hacia la realidad poética de mayo del 68 , en la que la utopía había creado una brecha atemporal. Así pues, Último round crea un agujero hacia otro agujero, un túnel hacia otro túnel, que no se da en ningún otro de los libros de Cortázar y que traslada la fractalidad, del terreno exclusivamente

\footnotetext{
${ }^{5}$ El término Eón es la transcripción del griego aị̂v: aion (período de tiempo indefinido que alude a la eternidad. Se trata de un término que González Riquelme acuña para hablar de tiempo "desterritorializado" o negación del tiempo (2003: 41).
} 
ficticio (caso de 62) al mundo real, creando así un vínculo fugaz y por tanto eterno, entre el libro y el momento temporal histórico que curiosamente toma la forma de un no-tiempo.

La poetización de los grafitis en Último round supone un avance en la realidad $\mathrm{y}$, en el plano literario: Cortázar transmite lo que experimenta al leer los grafitis de los jóvenes en una ciudad que a su vez está revelada, esenciada, convertida en poesía por estos mensajes poetistas pintados en las paredes. Y lo hace sin ser consciente de que está relatando el intersticio (lo que se proponía y de cuya frustración daba cuenta en $62^{6}$ ).

Y cuando no busca contarlo es cuando finalmente logra hacerlo: lo atraviesa y cumple en la práctica su teoría de la participación a través del amor, ya superada el ansia de posesión de la esencia.

Para que Cortázar llegue hasta aquí, ha sido necesario un proceso que Cortázar desgrana así: "a lo largo de treinta años he pasado por tres fases, por tres etapas que solo al final pude comprender con claridad y que mis libros reflejan suficientemente [...] la etapa de estética pura, la etapa metafísica y la etapa histórica" (2006b: 640). Dichas etapas se corresponden con unas fases de ósmosis: una interpenetración creativa con la ciudad de París ${ }^{7}$.

Para revisar, muy brevemente, algunos de los puntos que nos aclaran esta teoría, en El perseguidor podemos hallar las bases de la experiencia poética existencial, la teoría del poeta como ser que "se traspone poéticamente al plano esencial de la realidad" (Cortázar 1994b: 285), y reside en el terreno de la intuición pura, las experiencias poéticas pre-científicas de un orden poético inalterado (el eón de Johnny), frente a un Bruno que representa la articulación lógica, el enunciado, el orden estético, el cronos. Asimismo, es observable el pasaje entre modos existenciales que supone el surrealismo en forma de juego con el tiempo, y la concepción del poeta como camaleón que, de una forma análoga al primitivo, descubre asociaciones que le transportan al tiempo mítico.

Por primera vez en la obra de Cortázar, vemos el enfrentamiento de cronos y eón, el tiempo "de los relojes", diría Johnny, y el tiempo mítico, el mundo racional frente al intuitivo, la lógica frente a la poesía, y el mundo occidental frente al oriental. Todas estas contraposiciones se juegan en una sola baraja, todas nos vienen dadas por el desdoble de personajes o están contenidas en una sola forma o en un solo personaje que muestra una doble cara: véase Traveler frente a Horacio Oliveira, en Rayuela, o Hélène, en 62/Modelo para armar.

De este modo, el perseguidor se establece como figura poética puesto que no es ni más ni menos que la búsqueda de la mirada poética absoluta, reveladora de la superrealidad, como lo es Oliveira, como lo es Juan, en 62.

Esta búsqueda se articula a través de una continua dialéctica de contrarios, hasta el extremo de crear un juego entre materia y antimateria que desemboca en una síntesis creadora de una nueva realidad, la síntesis engendradora del "hombre nuevo". Por ello, esta dialéctica es la que teje las bases de la utopía de Cortázar en continuo desarrollo.

\footnotetext{
${ }^{6}$ Véanse primeros párrafos de la página 511 de este artículo.

${ }^{7}$ Para ampliar información sobre estas fases, véase Cortázar y París: Último round, donde se realiza un estudio de las mismas.
} 
En todas sus obras se dan los dos elementos aparentemente antagonistas: Johnny y Bruno, la Maga y Oliveira, Hélène y Juan.

En cada una de estas dialécticas hay, básicamente, una confrontación entre el estadio atemporal y el temporal. Y, en definitiva, todos estos antagonismos se resumen en uno solo: París y Cortázar. Y, en último término, Cortázar y Cortázar.

A simple vista, el diálogo con la ciudad es imposible. Lo es desde el plano racionalista lógico, así nos lo muestran todas las obras de Cortázar a lo largo de los sesenta, en las que observamos la continua confrontación y la búsqueda frustrada.

Contra esta opacidad, contra la imposibilidad de la visión y del diálogo, contra la máscara, se rebela el poeta, a quien Cortázar describe como alguien que no quiere las cosas sino su esencia (la "cosa esenciada"): "en vez de fetiche, palabrasclave; en vez de danzas, música del verbo; en vez de ritos, imágenes cazadoras". (1994b: 285)

Esta persecución de la esencia a todos los niveles (literario, vital, ontológico) que se inicia con El perseguidor, llevándolo a una lucha continua contra la ciudad temporal, se compone, como decíamos, de unas fases osmóticas que se corresponden con las etapas vitales de Cortázar, y que se pueden resumir como excentración (dislocación para después llegar al centro), incendio y construcción mediante la batalla poetista (surrealismo-existencialismo), para llegar al amoricidio $^{8}$, concepto que utiliza Cortázar en Rayuela para referirse a una síntesis perfecta que abarca también el entendimiento final del amor: amoricidio versus suicidio.

Éste se plantea por primera vez en Rayuela, al final del proceso de Oliveira que, como poeta que ansía "purificarse de toda adherencia que no apunte a lo esencial" (1994b: 285), parte de una dislocación -de un saberse testigo ajeno en el mundo-, y prosigue con la necesidad de regeneración, de "incendio", para terminar con la disyuntiva que nos da la pista del amoricidio.

62/Modelo para armar traza un camino que lleva hacia la ciudad pero se pierde en una continuidad fractal opaca que Mac-Millan denomina "mise en abîme infinita por remisión de un elemento a otro" (2005: 126), de manera que el libro nos hace ver la doble cara del hueco como el todo y la nada en la que a menudo termina la tentativa de acceso. Ese hueco configura el relato, pone de manifiesto aquello que tapan las palabras (2007, tomo I: 73 ).

Como explica Saldaña,

la presencia de una voz manifiesta la ausencia de la conciencia que ha generado esa voz, creemos que el discurso nos significa y nos sitúa ante los demás cuando en realidad, lo que sucede es que nos disolvemos en el instante mismo en que nos manifestamos a través del lenguaje ( 2003:85).

En ese vértigo, 62/Modelo para armar nos muestra el mandala como psicoanálisis interior y la búsqueda de la unidad, donde la "la zona" es un nivel (que se queda en

\footnotetext{
${ }^{8}$ El término "amoricidio", considerado una "síntesis última" en Rayuela, alude claramente a un estadio atemporal en cuanto que reúne la conjunción de contrarios y específicamente de vida y muerte (en las que todo se resume), ya que se trata de un suicidio en el amor. Recordemos: "En este mundo las síntesis últimas están por escribirse [...] haría falta el amoricidio, por ejemplo, la verdadera luz negra, la antimateria que tanto da que pensar a Gregorovius". Cortázar, Rayuela (1991: 40).
} 
intento, pues no llega a participar de la esencia de la ciudad), y la trascendencia es otro superior. Todo ello se resume en una sola búsqueda: la de París por Cortázar.

En cuanto a los ensayos reflexivos, previos a Último round, en los que mejor ha cristalizado el proceso poético de Cortázar, hay tres ejemplos claros: "Del sentimiento de no estar del todo", "Casilla del camaleón" y "Morelliana siempre", que nos dan una idea de las tres partes principales en que se puede dividir la teoría del túnel y la trayectoria literaria de Cortázar: excentración o asombro, participación, y amoricidio, y muestran la posibilidad de una luz al final del túnel fractal en el que la pista es amar desde el otro, amar al otro, sin ansiar poseer su esencia.

Por eso Oliveira aprende a ver el París secreto desde la Maga (a hablar el lenguaje de la Maga) cuando realmente aprende a amar a la Maga y viceversa. Del mismo modo, Cortazar ve París cuando aprende a ver la poesía de la ciudad, es decir, a mirar desde el poeta ${ }^{9}$, descifrando los símbolos, las correspondencias, entrando en el trance poético de la ósmosis desde el que se establece otro diálogo con la ciudad al participar de su esencia ${ }^{10}$. Es preciso comprender que, aquí, París funcionará siempre como aquello que el poeta canta.

En Último round se nos invita a hacer el trayecto que comenzó en Rayuela, vinculado al proceso vital y literario de Cortázar, pero, esta vez, con llegada a su estación definitiva. Ya sin personaje perseguidor, sólo Cortázar creando el pasaje, con los ojos "desollados por el fuego heracliteano".

Encontramos, en este almanaque combativo, el paso siguiente a Rayuela, el siguiente a 62 y a La vuelta al día: la llegada al centro (antropofanía), donde la mise en abîme pierde su carácter opaco, se nos muestra claramente la apertura, la fractalidad, esta vez, se abre hacia la entrevisión de la edad de oro: "Yo vi la edad de oro, la sentí brotar en la ciudad como un tigre de espigas [...] Yo vi la ciudad de oro, se llamaba París en mayo" (2006a, tomo I: 115) dice Cortázar en su collage de Último round, "Noticias del mes de mayo" en el que poetiza las frases que los estudiantes escriben en los muros en mayo del 68.

Para componer la portada del libro, Cortázar extrae de la realidad y del texto de Último round, pequeños fragmentos que actúan a modo de poros de la esponja, descubren los huecos en el "asfalto" y guían hacia una reflexión a través del humor, a la vez que adelantan los contenidos (poros) que el lector encontrará en el libro. Así pues, fragmentos de cuentos como "Silvia" se alternan con citas de Calvino, Lenin o Cocteau, imágenes, "Cosas oídas", artículos extraídos de periódicos, entre ellos una crítica al propio Cortázar ${ }^{11}$, e indicaciones que imitan a la prensa escrita para guiar al lector hacia el contenido del libro: "¿a la nena se le rompió la muñeca?, sin compromiso consulte p. 248".

Se trata de un libro collage -tanto más en cuanto que incluye otro collage en su seno: "Noticias del mes de Mayo"- que repite el carácter lúdico de La vuelta al día

\footnotetext{
${ }^{9}$ Para ampliar información sobre la relevancia de este aspecto de la trayectoria literaria y vital de Cortázar, véase capítulo II del libro Cortázar y París: Último round.

${ }^{10}$ Con objeto de ilustrar esta teoría de la participación, Cortázar cita a John Keats: "si un gorrión viene a mi ventana, participo de su existencia y picoteo las arenillas". Cortázar, "Para una poética" (1994: 278).

${ }^{11}$ Cortázar añade la crítica de Ramiro Casasbellas, donde se le tacha de "pequeño-burgués con veleidades castristas", colocándolo bajo el titular irónico de "grandes biografías de nuestro tiempo", y le indica al lector que puede ir a la página del libro en la que encontrará su ensayo-carta sobre la situación del intelectual latinoamericano a modo de respuesta a esta y otras críticas.
} 
pero que, esta vez, ya desde el título y el formato, nos avisa de que el combatejuego hará inmersiones mucho más importantes y definitivas en la realidad.

En opinión de Mac-Millan, se trata de un libro "revolucionario" ya desde su presentación técnica: formato, tipografía, presencia de imágenes, etc., que "obliga al lector a una apertura hacia nuevos procesos mentales" (2005: 50).

En este sentido, este tipo de portada-despertador, como veremos, se halla en estrecha relación con el diseño de los periódicos estudiantiles y con el formato de los juegos que los estudiantes realizaban en las calles en el mes de mayo del 68, pues es, sobre todo, una alusión a la obra abierta o en proceso, al permanente juego-batalla contra el tiempo. Un juego que permite múltiples combinaciones, para que la obra en proceso se actualice a través de la integración dinámica de las partes.

Como decíamos, en el preciso momento en que Cortázar deja de buscar el fondo, lo encuentra, participa de él sin poseerlo, lo nombra cuando no precisa nombrarlo, y, tomando el lugar del poeta, establece el diálogo con la ciudad. Vaticinando este futuro encuentro, Cortázar había afirmado en su "Para una poética":

en las formas absolutas del acto poético, el conocimiento como tal (sujeto cognoscente y objeto conocido) es superado por la directa fusión de esencias: el poeta es lo que ansía ser. (Dicho en términos de obra: el poeta es su canto) (1994b: 284).

Podemos decir que Último round es esta fusión, primera y única vez que accedemos a un claro centro en el "avance en la realidad", donde la cita "imposible" de Hélène y Juan en 62/Modelo para armar se ha cumplido. La poetización de los grafitis del mayo francés que lleva a cabo Cortázar en Último round supone la creación del doble pasaje hacia el corazón desnudo de la ciudad secreta. La primera vez que experiencia poética y relato se dan al mismo tiempo y que la palabra trasciende la palabra, igual que los mensajes trascienden los muros de la ciudad.

En este apartado del libro cristalizan diferentes planos de la literatura y la vida de Cortázar y también de su realidad más cercana. Por un lado, cristaliza el poetismo en las calles, que convierte los muros de París en poesía y que descubre la ciudad atemporal, la esencia de la ciudad vista desde la intuición pura, o como diría Cortázar, "tu más profunda piel” (Cortázar 2006a, tomo I: 203).

Cristaliza, por tanto, la ciudad poesía, la utopía de Cortázar esbozada en sus anteriores libros y ya definida aquí: "Yo vi la edad de oro sentí brotar en la ciudad como un tigre de espigas [...] relámpago entre dos nubes de petróleo" (Cortázar 2006a, tomo I: 115). Cristaliza también la identidad de Cortázar que, en su carta a Retamar, en el mismo libro, se confiesa como intelectual latinoamericano que elige la vía social basada en el "hecho humano esencial", para actuar, y el compromiso activo antes que una mera postura estética (giro último de la estética a la ontología). Y cristaliza, en definitiva, la concepción del amor de Cortázar que deja atrás la idea de posesión de Oliveira, en favor de la idea de participación expresada en "Morelliana siempre". Esta comprensión del lenguaje de la Maga desde el amor, comprensión de París desde la poesía y la esencia atemporal, hace que cristalice la 
poética de Cortázar unida, en el papel de Último round, a la poesía en las calles de París:

Por ósmosis, por lentos reflujos, a través de incontables síntesis, ocurre que de tanto anónimo trajinar asoma la excepción, el individuo que de alguna manera crea esa ciudad que lo creó, la modela otra vez exigentemente, la arranca al hábito y a la conformidad ${ }^{12}$.

Así, el acceso a la cosa esenciada, la cosa misma, se cumple en el encuentro del poeta con su canto. La palabra del poeta es la cosa misma, como diría Juan Ramón Jiménez, creada por su alma nuevamente. Cortázar crea París desde parís.

París, entendida como canto del poeta, como utopía, idea nítida del amor, centro del mandala, identidad y ser atemporal de Cortázar, ha alcanzado su definición. Ella y Cortázar ya son uno. Ello permitirá la escritura posterior de Prosa del observatorio (1971) en la que la poesía se une de nuevo a una utopía. París se ha hecho visible. De ahora en adelante, se tratará de narrar la ciudad a través de la prosa poética, la ciudad como esa vieja conocida que se ha transformado a la vez que el escritor que la asimiló y la generó, a través de los años, pasando de una etapa esteticista a una histórica de compromiso, de la primera ósmosis y el despertar, a la definición del amor y la poética en la cumbre de un proceso.

Cortázar se despide, en su texto "París, último primer encuentro", escrito en 1977 e incluido posteriormente en Papeles inesperados, de aquel escritor de la primera etapa, que, a finales de los años cincuenta, trazaba la génesis de Rayuela, persiguiendo un París inaccesible: "aquel París, aquel yo, no están ya" (2010: 190), afirma. Y le da la bienvenida a un diálogo continuado que ha inaugurado nuevas fases:

sé que nos amamos siempre y que seguimos acudiendo a la cita. Nada habrá cambiado mientras la ciudad y su amante continúen negando la superficie espumosa del tiempo para nadar en aguas profundas (Cortázar, 2010: 190).

En París: Ritmos de una ciudad (1982), un libro en el que Cortázar prologa las fotografías de Andrade, Cortázar ya no inventa personajes para tratar de explorar los prismas de París: tras el acceso al centro del mandala en Último round, puede alcanzar todos los ángulos de la ciudad (como pretendía Oliveira).

Cortázar nos despliega París, su París, en forma de cuadro impresionista, para que, como sucede en Último round, la entrevisión se genere a partir de la brecha abierta por el conjunto.

\section{Referencias bibliográficas}

Alazraki, Jaime, “Imaginación e historia en Julio Cortázar", en Fernando Burgos (edc.). Los ochenta mundos de Cortázar: ensayos. Madrid: EDI-6, 1987.

\footnotetext{
${ }^{12}$ Extraído del libro que alterna fotografía urbana con texto de Cortázar (D'Amico y Cortázar 1968: 68).
} 
— "Estructura" y "Cortázar antes de Cortázar. Rayuela desde su primer ensayo publicado: 'Rimbaud' (1941)”, en Julio Ortega y Saúl Yurkievich (edc.). Rayuela. Paris: Allca XX, 1991.

Andrade, Alecio y Julio Cortázar (con texto de Julio Cortázar). París: ritmos de una ciudad. Barcelona: Edhasa, 1982.

Baena, Enrique. El ser y la ficción. Teorías e imágenes críticas de la literatura. Barcelona: Anthropos, 2004.

- Umbrales del imaginario. Ensayos de estética literaria en la modernidad. Barcelona: Anthropos Editorial, 2010.

Batres, Izara. Cortázar y París: Último round. Madrid: Xorki, 2014.

Béhar, Henri (dir.). Le livre surréaliste. Actes du colloque en Sorbonne. París: Mélusine IV. Cahiers du Centre de Recherches sur le surréalisme, 1981.

Boldy, Steven. 62/modelo para armar, en The novels of Julio Cortázar. Cambridge: Cambridge Iberian and Latinoamerican Studies, 1980.

Breton, André. Manifiestos del surrealismo. Madrid: Visor, 2002.

Cortázar, Julio

-Los Reyes. Buenos Aires: Sudamericana, 1949.

- El examen. Buenos Aires: Sudamericana, 1986.

- El perseguidor (Las armas secretas), en Ceremonias. Buenos Aires: Sudamericana, 1970.

—Pameos y meopas. Barcelona: Llibres de Sinera, 1971.

—_Estrictamente no profesional”, en Territorios. México: Siglo XXI Editores, 1978.

- Deshoras. Madrid: Alfaguara, 1982.

- Historias de Cronopios y de famas. Madrid: Alfaguara, 1983.

- Bestiario. Madrid: Alfaguara, 1987

-Octaedro. Madrid: Alianza Editorial, 1987.

-Un tal Lucas. Barcelona: Ediciones B, 1989.

—Rayuela. Edc. de Julio Ortega y Saúl Yurkievich, Paris: ALLCA XX, 1991.

- Teoría del túnel, en Saúl Yurkievich (edc.). Julio Cortázar. Obra crítica/I. Madrid: Alfaguara, 1994a.

— "Para una poética" y "Algunos aspectos del cuento", en Jaime Alazraki (edc.). Julio Cortázar. Obra crítica /II. Madrid: Alfaguara, 1994b.

- Julio Cortázar. Obra crítica/III. Edc. de Saúl Sosnowski. Madrid: Alfaguara, 1994c.

- Diario de Andrés Fava. Madrid: Alfaguara, 1995.

- Salvo el crepúsculo. Madrid: Alfaguara, 1996.

— Julio Cortázar. Cuentos completos. 2 vols. II. Madrid: Alfaguara, 1998.

- Prosa del observatorio. Barcelona: Lumen, 1999.

- Julio Cortázar. Cartas. 3 vols. Edc. de Aurora Bernárdez. Buenos Aires: Alfaguara, 2000.

-Fantomas contra los vampiros multinacionales. Barcelona: Destino, 2002.

-62/Modelo para armar. Madrid: Santillana Ediciones Generales, 2004a.

—Libro de Manuel. Madrid: Santillana Punto de Lectura, 2004b.

-Los premios. Madrid: Santillana Ediciones Generales, 2004c.

-Último round. 2 tms. México: Siglo XXI, 2006a.

- Julio Cortázar. Obra crítica/VI. Edc. de Saúl Yurkievich. Barcelona: Galaxia Gutenberg, 2006b.

- La vuelta al día en ochenta mundos. México: Siglo XXI, 2007.

- Papeles inesperados. Madrid: Santillana-Punto de Lectura, 2010.

D'Amico, Alicia, Sara Facio y Julio Cortázar (con texto de Cortázar). Buenos Aires, Buenos Aires. Buenos Aires: Sudamericana, 1968.

Eliade, Mircea: Imágenes y símbolos. Madrid: Taurus Ediciones, 1974. 
Fernández-Braso, Miguel, "Cortázar: Último round”, en Jordi García. La llegada de los bárbaros. Barcelona: Edhasa, 2004, pp. 694-697.

Filer, Malva E. Los mundos de Julio Cortázar. Nueva York: Las Américas Publishing Company, 1970.

- "El lugar de la poesía. Pasos hacia la ciudad de 62/Modelo para armar", en Fernando Burgos (ed.). Los ochenta mundos de Cortázar: ensayos. Madrid: EDI-6, 1987.

Garrido Domínguez, Antonio. El texto narrativo. Madrid: Síntesis, 1996.

- Teorías de la ficción literaria. Madrid: Arco Libros, 1997.

-Narración y ficción. Literatura e invención de mundos. Madrid: Iberoamericana, 2011.

Goloboff, Mario. Julio Cortázar. La biografia. Buenos Aires: Seix Barral, 1998.

González Bermejo, Ernesto. Conversaciones con Cortázar. Barcelona: Edhasa, 1978.

_ "La idea central de Rayuela es una especie de petición de autenticidad total del hombre", en Rayuela. Edición de Julio Ortega y Saúl Yurkievich. Paris: ALLCA XX, 1991.

González Riquelme, Andrés, "La máquina musical en El perseguidor, de Julio Cortázar", Acta literaria, $\mathrm{n}^{\circ}$ 28, 2003, pp. 33-44.

Guigon, Emmanuel, “Anatomía del collage”, en Juan Ismael, antológica. Las Palmas de Gran Canaria: Centro Atlántico de Arte Moderno, 1998.

Harss, Luis, "Cortázar o la cachetada metafísica", en Los nuestros. Buenos Aires: Sudamericana, 1981, pp. 252-300.

Herráez, Miguel. Julio Cortázar. El otro lado de las cosas. Barcelona: Editorial Ronsel, 2003.

Hoyos Gómez, Camilo. La imagen literaria de París. Tesis Doctoral. Barcelona: Universidad Pompeu Fabra, 2010.

Huárag, Eduardo, "Cortázar y la heterogeneidad discursiva en Último round", Lexis. Revista de lingüistica y Literatura, 28 (2004): 555-570.

Mac-Millan, Mary. El intersticio como fundamento poético en la obra de Cortázar. Frankfurt: Peter Lang, 2005.

Prego, Omar. La fascinación de las palabras. Conversaciones con Julio Cortázar. Barcelona: Muchnik Editores, 1985.

Riobó, Victoria, "El libro-objeto en la obra de Julio Cortázar", en Victoria Riobó (ed.). Borges-Cortázar. Penúltimas lecturas. Buenos Aires: Circeto, 2007.

Saldaña, Alfredo. El texto del mundo. Crítica de la imaginación literaria. Zaragoza: Colección Trópica, 2003.

Shafer, José P. Los puentes de Cortázar. Buenos Aires: Nuevohacer, 1996.

Sosnowski, Saúl. Julio Cortázar: una búsqueda mítica. Buenos Aires: Noé, 1973.

Spies, Werner, "Los desastres del siglo", en AA.VV. Max Ernst, Une semaine de Bonté: los collages originales (Cat. Exp.). Madrid: Fundación Mapfre, 2009.

Yurkievich, Saúl, "La pujanza insumisa" y "Eros ludens (juego, amor, humor, según Rayuela)", en Rayuela. Edc. de Julio Ortega y Saúl Yurkievich. Paris: ALLCA XX, 1991.

—Julio Cortázar: mundos y modos. Madrid: Anaya \& Mario Muchnik, 1994. 